\author{
Agnieszka Izdebska \\ Katedra Teorii Literatury \\ Uniwersytet Łódzki \\ e-mail: agniz@poczta.onet.pl
}

\title{
W Kanadzie, w domu, w kuchni, na linoleum - o opowiadaniach Alice Munro
}

Najbardziej znany i najczęściej cytowany fragment prozy Alice Munro pochodzi z tomu Dziewczęta i kobiety (Lives of Girls and Women), który ukazał się w 1971 roku$^{1}$. Owo zdanie, jak pisze Dorota Filipczak, „zrobiło w krytyce zawrotną karierę" 2 , a brzmi następująco: „Życie w Jubilee jak wszędzie było nudne, banalne, zdumiewające i niepojęte - głębokie pieczary wyłożone linoleum" [s. 348-349] ${ }^{3}$. W polskim tłumaczeniu ginie określenie owego linoleum jako kuchennego (w oryginale to kitchen linoleum) ${ }^{4}$, niemniej przywołana tu fraza ilustruje też inne aspekty - poza podkreślonym przez Filipczak kon-

1 Polskie tłumaczenie autorstwa Pawła Łopatki ukazało się w 2013 r. Wszystkie cytaty $\mathrm{w}$ moim artykule pochodzą z tego wydania.

2 D. Filipczak, Pod "powierzchnią życia” - twórczyni i Femme Maison w prozie Alice Munro, „Teksty Drugie” 2014, nr 4, s. 217.

3 Nawiasem - takie "skrzydlate słowa" mają tendencję do lotów nieco odległych od rodzimych kontekstów. Przykład Coral Ann Howells (Canadian Gothic, w: Routledge Companion to Gothic, ed. by C. Spooner, E. McEvoy, London and New York 2007), która napisała: „Munro acknowledged her debt to women writers of the American South, especially Eudora Welty, for they both shared a similar vision of place, where people's lives are like »deep caves paved with kitchen linoleum « (Munro 1982:249)", stanowi dowód na to, jak cenne jest uważne sięganie do cytowanych tekstów.

4 Filipczak analizując ten fragment odnotowuje też konsekwencje innej, poza zgubieniem przymiotnika, niezbyt fortunnej, jej zdaniem, decyzji tłumacza: użycia określenia pieczary (oryginał to caves) zamiast bliższego rozmaitym Freudowsko-Jungowskim konotacjom słowa jaskinie (D. Filipczak, Pod "powierzchniq życia” - twórczyni i Femme Maison w prozie Alice Munro, s. 217). 
trapunktowym zestawieniem zwyczajności i podskórnej grozy, realizmu i gotycyzmu ${ }^{5}$ - świata opisywanego przez Munro. Otóż jej opowieści rozgrywają się w rzeczywistości, której przestrzenno-mentalnym punktem odniesienia są małe miasteczka na kanadyjskiej prowincji.

Fikcyjne Jubilee jest zatem nie tylko miejscem akcji, ale i istotnym elementem przywołanej powyżej powieści ${ }^{6}$ Dziewczęta $i$ kobiety, zaś równie emblematyczne Hanratty pojawia się w tomie Za kogo ty się uważasz? ${ }^{7}$, wydanym w 1978 roku. Oba miejsca wyraźnie wymodelowane są na Wingham w hrabstwie Hunron, w Południowym Ontario, gdzie dorastała pisarka ${ }^{8}$. Taka zresztą lokalizacja akcji - w jednym z wszechobecnych w kanadyjskim krajobrazie małych miasteczek - jest uznawana za typową dla literatury tego kraju ${ }^{9}$.

W swoich rozważaniach zamierzam analizować wymienione wyżej teksty z kilku powodów. Przede wszystkim uważam, że oba wczesne w twórczości pisarki utwory mają "założycielski" status: opowiadają bowiem o świecie, w którym tkwią źródła większości opowieści Munro. A rzeczywistość ta jest silnie przestrzennie uwarunkowana - Jubilee i Hanratty są jej fundamentem. Co więcej, obie powieści mogą być uważane za realizację konwencji Bildungsroman czy nawet Künstlerroman - są zatem opowieściami o dzieciństwie, do-

5 Tamże.

6 Używam tego określenia genologicznego, bo zgadzam się z diagnozą, że w obu przypadkach (tzn. tomu Dziewczęta i kobiety oraz Za kogo ty się uważasz?) mamy do czynienia z konwencją, którą w anglosaskiej nomenklaturze nazywa się short story novel, a zatem formą lokującą się pomiędzy powieścią skonstruowaną luźniej niż w realistycznym modelu a wyjątkowo spójnym zbiorem opowiadań. Zob. np. S. Becker, Gothic Forms of Feminine Fictions, Manchester/New York 1999, s. 137-138; też P. Seyersted, "Who Do You Think You Are?" Alice Munro and the Place of Origin, "American Studies in Scandinavia” 1992, Vol. 24, No 1, s. 17. Inne stanowisko w tej kwestii, uznając oba tomy za zbiory opowiadań, zajmuje choćby G. Lynch, No Honey, I'm Home. Place Over Love in Alice Munro's Short Story Cycle "Who Do You Think You Are?", "Canadian Literature" 1999 (Spring), nr 160, s. 74-76. Lynch zresztą w innym swoim tekście (The One and the Many: English Canadian Short Story Cycles, "Canadian Literature” 1991 (Autumn), nr 130) dowodzi, że zbiór opowiadań to forma - z rozmaitych powodów: filozoficznych, historycznych, mentalnościowych, a nawet politycznych i geograficznych - ulubiona i zaadaptowana przez pisarzy kanadyjskich (s. 93-94, 102).

7 W polskim tłumaczeniu Elżbiety Zychowicz powieść wyszła w 2012 roku. Z tego wydania pochodzą wszystkie cytaty w tekście.

8 Zob. P. Seyersted, "Who Do You Think You Are?”, s. 17. Seyersted pisze również, że niektórzy mieszkańcy rodzinnego miasteczka Munro poczuli się urażeni obrazem Jubilee w Dziezczętach i kobietach (tamże, s. 23).

9 Zob. N. Burke, Cityscapes - Canadian Urban Space as Portrayed in Selected Fiction and Non-Fiction, w: Komt ja Paik / Place and Location: Studies in Environmental Aesthetics and Semiotics III, eds. V. Sarapik, K. Tüür, Tallin 2003, s. 303. 
rastaniu (Dziewczęta i kobiety ${ }^{10}$ ) oraz dochodzeniu do dorosłości (Za kogo ty się uważasz?) bohaterek jako artystek, zaś zarówno sposób, w jaki ta formacja się odbywa, jak i jej rezultat, są zdeterminowane miejscem, z którego bohaterki pochodzą ${ }^{11}$. Ich historie zaczynają się w owych emblematycznych miasteczkach. Zarówno Del (bohaterka Dziewcząt i kobiet), podejmująca decyzję o wyjeździe z Jubilee, jak i Rose (główna postać Za kogo ty się uważasz?) opuszczająca Hanratty, by wrócić tam po latach, muszą poradzić sobie z dziedzictwem, które zawdzięczają tym miejscom. Każda z nich robi to inaczej żadna z nich go nie odrzuca. Choć łatwo uznać, że mamy zatem do czynienia z konstrukcją typową dla wspomnianej konwencji, to jednak kanadyjska pisarka dokonuje tu ciekawej modyfikacji tego stereotypu.

Alice Munro jest uważana, jeśli weźmiemy pod uwagę ściśle realistyczny aspekt jej opowieści, za pisarkę celnie odnotowującą i interpretującą kulturową historię Południowego Ontario, szczególnie zaś przemiany dokonujące się $\mathrm{w}$ porządku przestrzenno-społecznym małych miasteczek tego regionu ${ }^{12}$. Taki walor dokumentacyjny mają na przykład początkowe fragmenty Za kogo ty się uważasz?:

Mieszkali w ubogiej dzielnicy miasta. Było Hanratty i West Hanratty, podzielone rzeką. Oni mieli dom w West Hanratty. Społeczność Hanratty była bardzo zróżnicowana, począwszy od lekarzy [...] i prawników, a skończywszy na odlewnikach, robotnikach i wozakach [...] W West Hanratty ta rozpiętość była dużo mniejsza - od robotników i odlewników do dużych utracjuszowskich rodzin sezonowych przemytników alkoholu, prostytutek i nieudolnych złodziei. W pojęciu Rose jej rodzina stała okrakiem nad rzeką i nie należała ani tu, ani tu, ale nie była to prawda. Ich sklep znajdował się jednak na terenie West Hanratty [...] [s. 14-15].

Zarówno Jubilee, jak i Hanratty to miejsca o silnie zaznaczonej stratyfikacji terytorialno-społecznej. W Dziewczętach $i$ kobietach przestrzeń również podlega społecznej waloryzacji, podział na miejsca lepsze lub gorsze jest tam wyraźny:

Droga na Moczary była ostatnim miejscem na świecie, w którym chciała mieszkać matka. Gdy tylko dotykała stopą chodnika w miasteczku i unosiła

10 Można nawet powiedzieć, że w tym przypadku to opowieść zdublowana: poznajemy w niej bowiem również, w opowiadaniu Księżniczka Ida, zarys historii matki Del.

11 Zob. G. Lynch, No Honey, I'm Home, s. 74.

12 Zob. J. Weaver, Society and Culture in Rural and Small-Town Ontario: Alice Munro's Testimony on the Last Forty Years, w: Patterns of the Past: Interpreting Ontario's History, eds. R. Hall, W. Westfall, L.S. MacDowell. Toronto 1988, s. 381. 
głowę, szczęśliwa, że wchodzi w cień, zostawiając w tyle upalną Drogę, emanowało od niej poczucie ulgi, poczucie nowego sensu [...]. Matka poprawiała mnie, gdy mówiłam, że mieszkamy przy Drodze na Moczary. Powtarzała, że mieszkamy na jej końcu, tak jakby mogło to coś zmienić. Potem okazało się, że Jubilee to także nie jej miejsce, na razie trzymała się go z nadzieją i radością i pilnowała, by ją dostrzegano [...] [s. 18].

W przywołanym powyżej cytacie pojawia się jednak jeszcze jeden wątek. Otóż owo miejsce opisywane przez Del jest przestrzenią "pomiędzy”. Czytamy: „Droga na Moczary nie była częścią miasteczka, ale też nie była częścią wsi" [s. 16]. Heather Murray pisze nawet o podobnych miejscach w utworach kanadyjskich pisarek jako o "pseudo-pustkowiu”, obszarze pomiędzy lasem, naturą ${ }^{13}$ a miastem. To taka przestrzeń, w którą wpisane są nie tylko możliwości obu tych miejsc, ale i to, że ewokuje ruch, przemieszczanie się pomiędzy nimi ${ }^{14}$. Obie bohaterki pochodzą zatem z miejsc granicznych, przenoszą się bezustannie raz na dłużej, raz na krócej z jakiegoś "tu” rzadko satysfakcjonującego, do budzącego nadzieję "tam”. Bardzo wyraźnie ten aspekt świata Munro pokazany jest w Za kogo ty się uważasz?, gdy Rose zaczyna chodzić do szkoły średniej, za most i przekracza granicę dzielącą "pseudo-pustkowie", czyli West Hanratty i miasteczko właściwe. W czasie lekcji "higieny i zasad zdrowotnych” Rose usadowiona „w tylnych ławkach miejskiej części" na pytanie o swoje śniadaniowe menu odpowie odważnie: „połówka grejpfruta”. Chciała bowiem „sprzymierzyć się z mieszkańcami miasteczka przeciwko miejscu, skąd pochodziła, pragnęła przyłączyć się do tych jedzących gofry i pijących kawę, powściągliwych i znających się na rzeczy posiadaczy wnęki kuchennej" [s. 74]. Potem wielokrotnie dogania ją rozlegający się za jej plecami okrzyk „połówka grejpfruta”, a ona będzie udawać, że go nie słyszy, ocierając niepostrzeżenie pot z górnej wargi. Jak bowiem pisze Munro, „Pocimy się z powodu naszych aspiracji” [s. 75]. Jednak wkroczenie na terytorium „właściwego" Hanratty zmienia Rose i fizycznie, i mentalnie:

13 A owa natura w literaturze kanadyjskiej jest bardzo specyficznie reprezentowana i waloryzowana. Zob. na przykład M. Atwood, Survival. A thematic Guide to Canadian Literature, Toronto 1996, s. 45-86. Przywoływany tu rozdział nosi znaczący tytuł Nature the Monster, aczkolwiek w swojej książce Atwood pokazuje, jak spolaryzowany jest obraz natury w jej rodzimym piśmiennictwie, oscylujący między arkadyjskością Wyspy Księcia Edwarda a zabójczą Północą, bezwzględną dla osadników.

14 Zob. H. Murray, Women in the Wilderness, w: A Mazing Space: Writing Canadian Women Writing, eds. S. Kamboureli, S. Neumann, Edmonton 1986, s. 76; za S. Becker, Gothic Forms of Feminine Fictions, s. 126-127. 
Od kiedy Rose zmieniła otoczenie, przekroczyła most, bardzo się zmieniła, stała się kronikarzem. Żadnych nerwów. Donośny, sceptyczny głos, kołysanie biodrami, spódnica w czerwono-żółtą kratę, dumny krok. Flo i Rose zamieniły się rolami. Obecnie to Rose przynosiła do domu rozmaite historyjki [s. 77].

Kiedy z kolei matka i Del przenoszą się do wynajętego w miasteczku domu, dziewczynka zaczyna dostrzegać uroki Drogi na Moczary, owego „pomiędzy":

Brakowało mi bliskości rzeki i mokradeł, a także prawdziwej anarchii zimy, zamieci śnieżnych, które zamykały nas przed światem szczelnie jak w Arce Noego. Niemniej lubiłam ład, harmonię, zawiły porządek miejskiego życia, dostrzegalny jedynie dla przybysza z zewnątrz [s. 105].

Ten ruch wymuszany przez miejsca graniczne dla obu protagonistek stanowi część ich dojrzewania, budują siebie przez te doświadczenia zysku i utraty.

Hierarchia przestrzenno-społeczna owych miejsc podlega jednak nieuchronnym przekształceniom historycznym: z czasem Hanratty się zmienia, zanika tak silna stratyfikacja: „Stary most został rozebrany, na jego miejsce zbudowano nowy, szeroki most, znacznie mniej wyrazisty. Różnica między Hanratty a West Hanratty była teraz prawie niezauważalna" [s. 300]. Zmianie natomiast nie podlega pewien porządek świata, z którego dość jasnym obrazem Del i Rose opuszczają swoje miasteczka.

Kwestia zasad, na których Munro funduje rzeczywistość kreowaną w swoich utworach wiąże się z inną, równie często, co cytowana tu na początku fraza, przywoływaną wypowiedzią pisarki. W wywiadzie udzielonym Graeme’owi Gibsonowi powiedziała: „Ta część Kanady, z której pochodzę, jest absolutnie gotycka. Nie sposób się od tego odciąć" ${ }^{15}$. Jakkolwiek ową gotyckość komentować ${ }^{16}$, doskonale współbrzmi ona $\mathrm{z}$ cytowanym na wstę-

15 "The part of the country I come from is absolutely Gothic. You can't it all down" (G. Gibson, Alice Munro, w: tegoż, Eleven Canadian Novelists, Toronto 1973, s. 248). Cytat ten stał się mottem rozdziału poświęconego kanadyjskiej literaturze gotyckiej $\mathrm{w}$ przywoływanej już tu książce Routledge Companion to Gothic (s. 105).

16 A sam termin - wobec swojej mglistości - daje niemal niegraniczone pole interpretacyjne. Posługiwanie się terminem gotycki w polskim literaturoznawstwie jest dodatkowo kłopotliwe, ponieważ ma on tutaj znaczenie węższe niż w literaturze anglosaskiej, a co za tym idzie, możliwa jest pomyłka: niektórzy mogą uznać, że autorozpoznanie Munro to jej definiowanie się jako pisarki tworzącej $\mathrm{w}$ duchu horrorów. Wobec obszerności bibliografii dotyczącej możliwych definicji konwencji i zakresów rozumienia terminu nie podejmuję się przedstawić tutaj nawet skrótowej listy lektur na ten temat. Zainteresowanym tą kwestią za punkt wyjścia może posłużyć na przykład przywoływana już książka The Routledge Companion to Gothic lub klasyczny tekst Davida Puntera, The Literature of Terror. The Gothic Tradition, London 1999 czy też późniejszy New Companion to the Gothic, Chichester 2014. 
pie zdaniem o życiu w Jubilee i wydobywa zarówno właściwości tego źródłowego świata, jak i niektóre cechy opowieści o nim. Wobec definicyjnego braku klarowności samego pojęcia, dla potrzeb dalszych analiz przyjmę za punkt wyjścia rozumienie gotycyzmu zaproponowane przez Katrin Berndt $\mathrm{w}$ tekście The Ordinary Terrors of Survival: Alice Munro and the Canadian Gothic. Definiuje ona gotyk jako formę wyrażająca nieokreślone, ciemne i należące do obszaru nieświadomości sfery życia. Podkreśla, że gotyk eksponuje ukryte, ambiwalentne znaczenia, wyraża strach tkwiący pod powierzchnią racjonalnego obrazu świata i przypomina czytelnikowi, że takie lęki mogą czaić się w tle najzwyklejszych, codziennych doświadczeń ${ }^{17}$. Berndt pisze też, że wobec tego, iż sporo tekstów Munro dotyka tematu okrucieństwa i grozy kryjącej się za fasadą surowej kalwińskiej moralności, można uznać ich przynależność do zjawiska określanego mianem gotyku z Południowego Ontario $^{18}$. Wedle Susanne Becker, analizującej w książce Gothic Forms of Feminine Fictions między innymi opowiadania Munro, owo doświadczenie, które zyskuje swój wyraz w gotyckiej formie, to przede wszystkim przeżycia kobiet. Bo, dodaje, gotycki horror zawsze miał wymiar domowy i rodzinny ${ }^{19}$. Becker używa w swoich rozważaniach dotyczących pisarstwa kobiet poręcznej formuły, pisząc o strategii "gotycyzowania” (gothicising) ${ }^{20}$ kobiecych doświadczeń, zatem o posługiwaniu się pewnymi elementami konwencji jako narzędziami przydatnymi do kreowania określonej wizji świata bez jednoznacznej genologicznej afiliacji.

W obu przywoływanych tu powieściach Munro dokonuje opisanego przez Becker zabiegu, choć w Dziewczętach $i$ kobietach jest on silniej obecny. Doskonale daje się go rozpoznać choćby w opisie domu matki głównej bohaterki:

17 Zob. K. Berndt, The Ordinary Terrors of Survival: Alice Munro and the Canadian Gothic, ,Journal of Short Story in English" 2010 (Autumn), nr 55, http://jsse.revues.org/1079 [dostęp 27.05.2014].

18 Berndt pisze: „I define the Gothic mode as addressing the indeterminate, obscure and subconscious spheres of life. It stresses the hidden, ambivalent meanings, expresses fears beyond logic and rational understanding, and reminds its readers that such anxieties may lurk beneath the surface of everyday, ordinary experience. This awareness distinguishes the writing of Alice Munro. Several of her stories portray the Ontario region in Canada with regard to the cruelties and horrors that hide behind the façade of rigid, Calvinist morality" (tamże). Sama pisarka podkreślała też wpływ, jaki na jej pisarstwo wywarła twórczość autorek z amerykańskiego Południa, Eudory Welty i Carson McCullers (zob. G. Gibson, Alice Munro, s. 248). Ja do tej listy literackich powinowactw dorzuciłabym bezwzględnie opowiadania Flannery O'Connor, choć mroczność świata pokazywanego w jej prozie nie do końca przekłada się na świato-kreacje Munro.

19 S. Becker, Gothic Forms of Feminine Fictions, s. 4.

20 Tamże, np. s. 104. 
Na początku, na samym początku był dom. [...] Dom, którego nigdy nie widziałam na zdjęciu, bo może nikt go nie sfotografował, a który matka niezmiennie opisywała zniecierpliwionym, rzeczowym tonem [...], jawił mi się tak wyraźnie, jakbym kiedyś widziała go w gazecie - jako najbardziej obnażony, najmroczniejszy, najwyższy ze wszystkich domów z drewna, prosty i bliski, a jednak groźny, kryjący zło jak miejsce, w którym popełniono zbrodnię [s. 11].

Nastrój grozy emanujący z domostwa zdaje się rzutować na cały otaczający je świat: „wokół panował wieczny listopad [...] rosły upiorne krzewy, a dziwne, raptowne podmuchy wiatru unosiły ich gałęzie, jedną po drugiej" [s. 11]. Ten nieco ostentacyjny opis godny ruin zamczyska lub opuszczonego domu na pustkowiu to obraz drewnianego domu na kanadyjskiej prowincji. Obraz, który wraca w tomie w różnych odsłonach, jak choćby w odniesieniu do siedziby sąsiadów bohaterki, trudniących się przemytem alkoholu Potterów: „Ich dom zdawał się ucieleśniać tak wielkie zło i tajemnicę, że bałam się spojrzeć na niego choćby ukradkiem i zawsze mijałam go ze wzrokiem utkwionym przed sobą, żeby opanować odruch ucieczki" [s. 17].

Zgodnie z wymogami konwencji, wnętrza owych gotycyzowanych domów nabierają cech labiryntu. Tak dzieje się w opowiadaniu Następcy żywego ciała z tomu Dziewczęta i kobiety, gdy bohaterka zostaje zmuszona do uczestniczenia w uroczystościach pogrzebowych jednego z krewnych:

Dom przypominał łamigłówkę, labirynt z czarną kropką w jednym z kwadratów czy pomieszczeń, do którego trzeba było dotrzeć. W tym przypadku czarną kropką było ciało wujka Craiga, a mnie zależało nie na tym, by do niego trafić, lecz by je ominąć, nie otworzyć nawet najmniej groźnie wyglądających drzwi, z obawy przed tym, co się za nimi kryje [s. 76].

Del nie uda się jednak umknąć przed ową „udomowioną” grozą. Mimo ugryzienia $\mathrm{w}$ ramię droczącej się z nią kuzynki, uznana za nadmiernie wrażliwą, uspokojona herbatą i ciastem dziewczynka zostanie jednak doprowadzona do zwłok wujka Craiga, by mogła się z nim pożegnać. Przed domami Jubilee i rządzącymi w nich prawami nie ma bowiem łatwej ucieczki.

Kolejnym dziwacznym domem w miasteczku jest siedziba wujka Benny'ego, jednej z licznych u Munro postaci dziwaków zamieszkujących kanadyjską prowincję. Pokoje budynku całkowicie zajęte są nagromadzonymi tam zużytymi, tworzącymi chaotyczny labirynt sprzętami: „Było to po prostu kilka rozpoznawalnych przedmiotów, które wyróżniały się na tle istniejącego pandemonium, nieprzebranej masy ciemnych gnijących dywanów, linoleum, części mebli, wnętrzności jakiejś maszynerii, gwoździ, drutu, narzędzi i różnych przyborów" [s. 13]. W tym zbiorze na werandzie znajdują się stosy gazet wypełnionych sensacyjnymi wiadomościami, na przykład o tym, że „OJCIEC 
KARMI ŚWINIE BLIŹNIACZKAMI”, „KOBIETA WYSŁAŁA TORS MĘŻA W PACZCE" [s. 14]. Bohaterka, Del, zaczytuje się nimi, a potem oszołomiona wraca do domu:

Wprost rozsadzały mnie i przyprawiały o zawrót głowy rewelacje o złu, jego różnorodności, o tym, jak bywa wymyślne i przerażająco swawolne. Ale im bardziej zbliżałam się do domu, tym szybciej te obrazy blakły. Dlaczego prosty mur budynku, blada wyszczerbiona cegła, cementowy stopień przed drzwiami do kuchni [...] podawały w wątpliwość, że jakaś kobieta posłała przyjaciółce w Karolinie Południowej tors męża zawinięty w świąteczny papier [s. 15].

Świat wujka Benny'ego - klasycznie gotycki - wydaje się jednak bohaterce osobny, inny od tego, w którym żyje ona sama. Dociera to do niej z całą mocą, gdy wuj wraca $\mathrm{z}$ zakończonej fiaskiem wyprawy do Toronto, gdzie usiłuje odnaleźć swoją korespondencyjnie poznaną młodocianą żonę, która katuje zresztą pod jego dachem własne dziecko, czemu on nie potrafi się przeciwstawić:

Obok naszego świata istniał więc świat wujka Benny'ego, jak niepokojące odbicie, taki sam, a jednak inny. $\mathrm{W}$ jego świecie człowiek mógł utonąć w ruchomych piaskach, paść ofiarą duchów lub przerażających zwykłych miast, szczęście i nikczemność były gigantyczne i nieprzewidywalne, nie zasługiwało się na nic, mogło się wydarzyć wszystko, a porażki odbierano z obłąkańczą satysfakcją. Pokazując go nam, wujek odniósł triumf, którego nie mógł być świadom [s. 42].

W tomie Za kogo ty się uważasz? owa groza świata, pojawiająca się pod postacią udomowionej przemocy, pokazana jest bardziej przejmująco, bo przybiera formę absolutnie jawną i wpisującą się w rodzinną codzienność. Najwyrazistszym przykładem takiej postaci gotycyzowanego doświadczenia jest opowiadanie Królewskie lanie. Część jego akcji rozgrywa się w kuchni, w której Flo, macocha Rose, zmywa podłogę pokrytą „sześcioma różnymi wzorami linoleum”. To dzieło jej zapobiegliwości, bowiem: „nakupowała za grosze resztek i pomysłowo przycięła je i dopasowała, wykańczając paskami i pinezkami" [s. 30]. W pewnym momencie, zirytowana prowokacyjnym zachowaniem Rose recytującej na zmianę z młodszym, przyrodnim bratem, idiotyczne i wulgarne, w mniemaniu Flo, wierszyki, uznaje, że pasierbica przesadziła i wzywa męża, by przywołał dziewczynkę do porządku. Ten ekscentryczny stolarz reperujący meble zabiera się za spuszczenie córce „królewskiego lania".

Jego twarz, podobnie jak głos, są bez wyrazu. Przypomina kiepskiego aktora grającego $\mathrm{w}$ grotesce. Jak gdyby musiał delektować się czymś żenującym i okropnym i trwać przy tym. 
$[\ldots]$

Rose próbuje wpatrywać się w kuchenną podłogę, pomysłową i krzepiącą geometryczną kompozycję, żeby tylko nie patrzeć na ojca lub jego pas. Jak coś takiego może się dziać w obecności takich codziennych świadków - linoleum, kalendarza z młynem, rzeczką i jesiennymi drzewami, starych, usłużnych garnków i patelni? [...] Ci świadkowie ci nie pomogą, żaden z nich nie może jej uratować. Te przedmioty stają się obojętne, bezużyteczne, nawet nieprzyjazne. Garnki potrafią okazać nienawiść, wzory na linoleum łypią na ciebie, zdrada jest drugim obliczem codzienności [s. 33-34].

Rzeczywiście pomoc nie nadchodzi i rytuał królewskiego lania toczy się swoją koleją, wedle reguł znanych obu stronom:

Przy pierwszym, a może drugim bolesnym razie Rose się cofa. Nie pogodzi się z tym. Okrąża kuchnię, próbuje dostać się do drzwi. Ojciec zastępuje jej drogę. W dziewczynce nie ma ani odrobiny odwagi, stoicyzmu. Ucieka, krzyczy, błaga. [...] Teraz ojciec wymierza jej cios pięścią w twarz. [...] Rose woła coś bez ładu i składu [...] Flo także wrzeszczy. „Przestań, przestań!” Jeszcze nie. Ojciec obala Rose na podłogę, a może ona sama się na nią rzuca. Znów kopie ją po nogach. [...] Z ust Rose wyrywa się ostatni okrzyk poniżenia i obrony, wygląda bowiem na to, że musi odegrać swoją rolę z taką samą jaskrawością i przesadą jak jej ojciec. Gra ofiarę z brakiem umiaru [...] Mogłoby się wydawać, że dadzą z siebie wszystko, posuną się do ostateczności. Niezupełnie. Ojcu nigdy nie udało się poważnie zranić Rose, chociaż oczywiście zdarza się, że dziewczynka modli się, by to zrobił. Uderza ją otwartą dłonią, zachowuje pewną powściągliwość w kopaniu [s. 34-35].

Rose po egzekucji, teatralnie potykając się na schodach, idzie do swego pokoju, gdzie osiąga „stan spokoju, w którym akt przemocy jest postrzegany jako pełny i ostateczny" [s. 35]. Myśli o samobójstwie, a kiedy pojawia się Flo z kremem do posmarowania obrażeń pasierbicy, odrzuca jej chęć pomocy: jest wszak udręczoną ofiarą. Jednak gdy zjawia się potem taca apetycznych kanapek, ciasteczek i czekoladowy napój, Rose, zostawiona z nimi sam na sam, ulega atakowi łakomstwa i wie, że tym samym straciła przewagę:

Zrozumie, że życie znów się zaczyna, że wszyscy będą siedzieli przy stole, jedząc, słuchając wiadomości w radiu. Jutro rano, może nawet dzisiaj wieczorem. Choć wydaje się to niestosowne i nieprawdopodobne. Będą zakłopotani, ale raczej mniej, niż można byłoby się spodziewać, zważywszy na to, jak się zachowywali. Będą odczuwali dziwne znużenie, ozdrowieńczą ociężałość, niezbyt odległą od zadowolenia [s. 38].

Królewskie lanie bywa zwieńczone akrobatycznym popisem Flo, która po kolacji wykonuje w kuchni ekwilibrystyczne obroty, ku entuzjazmowi całej rodziny: „by odwrócić ich uwagę, lub nawet w ramach przeprosin” [s. 39]. 
W tę rodzinną opowieść, osnutą wokół tytułowego rytuału, włączona jest też inna historia z Hanratty - anegdota o Becky Tyde, karlicy "o dużej głowie, gromkim głosie i ruchach jakiejś bezpłciowej istoty" [s. 17]. Poznajemy okoliczności śmierci jej ojca, o którym w miasteczku mówi się, że katuje córkę, więc grupa mężczyzn bije go niemal na śmierć przed jego własnym domem. Gdy na wpół żywy czołga się po śniegu i usiłuje dostać do wnętrza, Becky nie otwiera mu drzwi. Jak zeznaje w sądzie, nie chciała się przeziębić. To jedna z wielu opowieści z życia kanadyjskiej prowincji, które snuje Munro. Trudno tu mówić nawet o "głębokich pieczarach wyłożonych linoleum". Wydaje się raczej, że ta udomowiona, kuchenna groza kryje się tuż pod powierzchnią rodzinnego życia, wpisana jest w codzienność jako jej niezbywalny element. Przy czym - co ciekawe - protagonistki tych opowiadań odbierają tę cechę rzeczywistości jako relatywną. Rose doznaje na przykład autentycznego zdumienia, zetknąwszy się z zamożną rodziną narzeczonego, ludźmi, którzy w warunkach kanadyjskich mają pozycję niemal arystokracji:

Nigdy nie wyobrażała sobie, że tyle wrogości może się skumulować w jednym miejscu. Billy Pope był bigotem i zrzędą, Flo była kapryśna, niesprawiedliwa i lubiła plotkować, ojciec był skłonny do zimnych osądów i nieustannej dezaprobaty. Ale w porównaniu z rodziną Patricka, rodzina Rose wydawała się wesoła i zadowolona [s. 150].

Tak komentuje obiad w gronie rodzinnym ktoś, kto przeszedł trening „królewskiego lania", szkołę podstawową w Hanratty i zna historię karlicy Becky Tyde. Paradoksalnie dzieje się tak właśnie dlatego, że Rose dorastała na „pseudo-pustkowiu” West Hanratty, doświadczyła dzikiej przemocy farmerskich synów, wyrośniętych chłopców przetrzymywanych w szkole ze względu na brak pracy dla nich i doskonale przyswoiła sobie kolejny fragment wiedzy na temat praw rządzących światem, w którym musi żyć. W opowiadaniu Przywilej czytamy:

Rose wierzyła w niezmienność porządku rzeczy w szkole, w zasady różne od tych, które mogła zrozumieć Flo, w nieprzewidywalne okrucieństwo. Sprawiedliwość i czystość postrzegała obecnie jako niewinne pojęcia z prymitywnego okresu swego życia. Gromadziła pierwszy zasób rzeczy, o których nigdy nie powie [s. 48].

Rose, która sama rozporządza zbiorem „niewyrażalnych” doświadczeń, najwyraźniej potrafi rozpoznać zasoby cudze. 
W przywoływanej już tu scenie cyrkowego popisu Flo, wieńczącego terapeutyczną rodzinną kolację, macocha Rose pokazana zostaje jako jedna z długiego szeregu postaci - żeby posłużyć się określeniem Magdalene Redekop - matek-klaunów ${ }^{21}$ przewijających się przez większość opowieści Munro. Zdaniem Becker w centrum świata prozy Munro, świata przybierającego formę przestrzennych lub mentalnych labiryntów, tkwi właśnie ta figura ${ }^{22}$. Jeśli pociągnąć tę metaforę, zarówno Rose, jak i Del wracają do swoich miasteczek, bo w tej przestrzeni muszą się zmierzyć ze swymi matkami-klaunami, niegdyś naśladowanymi, później odrzuconymi i przynoszącymi dotkliwy wstyd, a teraz - niczym Jungowski cień - domagającymi się akceptacji, uznania, że to, co przez obie bohaterki odrzucone, stanowi też część ich samych.

Bowiem głównym tematem obu powieści, zwłaszcza Za kogo ty się uważasz?, jest próba udzielenia odpowiedzi na pytanie o własną tożsamość. Zdaniem Geralda Lyncha, opowieść Munro skonstruowana jest polemicznie wobec obowiązującego w literaturze kanadyjskiej stereotypu, który sprowadza tę kwestię do konieczności pojawienia się w życiu protagonistki splotu kilku elementów: miłości oraz przebaczenia i akceptacji, nieodłącznie związanych $\mathrm{z}$ miejscem pochodzenia ${ }^{23}$. Lynch twierdzi, że Rose, jako postać, nie ulega ułudzie osiągnięcia poczucia autonomicznej, esencjalnej tożsamości. Zauważa, że Munro - przez ciągle powracający motyw naśladowania innych i grania (Rose zostaje wszak aktorką) - konstruuje postać samostwarzającą się $\mathrm{w}$ serii zwierciadlanych odbić. Jego zdaniem pisarka raczej podkreśla tu trudność, niż eksponuje niemożliwość wypracowania skondensowanego, stabilnego "ja". Szczególnie widoczne jest to w scenach, kiedy Rose naśladuje swego szkolnego przyjaciela, Ralpha Gillespie, przedrzeźniającego Miltona Homera, który sam jest krzywym zwierciadłem

21 Zob. M. Redekop, Mothers and Other Clowns. The Stories of Alice Munro, London \& New York 1992. Redekop podkreśla, że Munro bezustannie multiplikuje figurę matki w rozmaitych postaciach, nie chodzi tu więc wyłącznie o kobiety mające dzieci: „Her stories are peopled with stepmothers, foster mothers, adoptive mothers, child mothers, nurses, old maids mothering their parents, lovers mothering each other, husbands mothering wives, wives mothering husbands, sisters mothering each other, and numerous women and men behaving in ways that could be described as maternal" (s. 4). To oczywiście wątek szalenie obszerny, którego zarysowanie rozsadziłoby objętościowe (i tematyczne zresztą) ramy mojego tekstu.

22 S. Becker, Gothic Forms of Feminine Fictions, s. 147-148.

23 Zob. G. Lynch, No Honey, I'm Home. Place Over Love in Alice Munro's Short Story Cycle, "Who Do You Think You Are?", "Canadian Literature” 1999 (Spring), nr 160. Pisze on: „In suggesting solutions to the endemically Canadian riddle of identity, Who Do You Think You Are? argues fictionally for the potentially definitive importance of love and for the abiding residence of forgiveness and affirmation in the place of origin" (s. 73-74). 
Hanratty. Ten upośledzony umysłowo mężczyzna, konsekwentnie rozbijający uroczyste parady $\mathrm{w}$ miasteczku, to postać pełniąca funkcję człowieka-karnawału ewokującego chaos jako rewers porządku rządzącego „właściwym" Hanratty ${ }^{24}$.

Kwestia tożsamości pojawia się też w Za kogo ty się uważasz? w ramach klasycznego gotyckiego motywu: sobowtóra. Zyskuje tu jednak niestereotypową, groteskową realizację. Gdy Flo buduje w domu łazienkę z toaletą, wydzielając na to część kuchni, okazuje się, że ściany nowego pomieszczenia nie dają żadnej izolacji akustycznej:

Wszyscy znali nawzajem swoje odgłosy [...] A że wszyscy byli ogromnie pruderyjni, udawali, że nic nie słyszą, albo nie słuchają, i nie robili żadnych uwag. Nie łączyli wychodzącej z łazienki osoby z kimś wydającym tamte dźwięki [s. 14].

Tej samej dwoistości w postrzeganiu innych doświadcza Rose, gdy słyszy absurdalny słowotok ojca zajętego pracą i wykrzykującego frazy w rodzaju:

Makaron, pepperoni, Botticelli, fasola... Co to mogło znaczyć? Rose powtarzała sobie te słowa, ale nie mogła go zapytać. Człowiek, który je wypowiadał, nie był tą samą osobą, co jej ojciec, chociaż zdawali się zajmować tę samą przestrzeń [s. 13].

Lynch dowodzi też, że w tym szeregu odbić, poprzez które Rose buduje swoją tożsamość, figurą istotną i kluczową jest Ralph Gilespie ${ }^{25}$. To przyjaciel ze szkoły, z którym odnajduje powinowactwo, by potem się dowiedzieć, że po wypadku w wojsku Ralph wraca do Hanratty i tam mieszka w domu weterana. Gdy się spotykają po latach, Rose właściwie nie dopuszcza go do głosu, radośnie monologując na temat jego zdolności naśladowania Mil-

${ }^{24}$ Gerald Lynch pisze: „is Rose at the end of the story cycle the self-deluding figure of similarly essentialist notions of autonomous selfhood? In its recurrent use of acting and imitation as a metaphor of self-construction [...] Who Do You Think You Are? does tend to produce characters who are reflections of reflections of reflections, as Rose imitating Milton Homer in the title story is actually imitating Ralph Gillespie imitating Milton Homer, that „mimic of ferocious gifts and terrible energy" (s. 192), who is himself something of a reflecting emanation of old Hanratty itself. In the mirror-in-a-mirror image, as in the regressus ad infinitum and the literary mise en abîme, Munro signals the difficulties of ultimately condensing, grounding and centring an ideal of self, though not necessarily the impossibility" (tamże, s. 75).

25 Jak zauważa Lynch: „Ralph Gillespie is for Rose, then, both a generative presence and a figure of entrapment within Hanratty, one who dies, as his obituary records, because "he mistook the basement door for the exit door and lost his balance" (s. 206). Rose found the exit [...] So it is Ralph [...] who can be read, if anyone can, as the measure to this point of Rose's liberated, limited success"' (tamże, s. 92). 
tona Homera. Potem, gdy czyta nekrolog Ralpha („Przypuszcza się, że mylnie wziął drzwi prowadzące do piwnicy za wyjściowe i stracił równowagę", „upadek okazał się niebezpieczny ze względu na dawne obrażenia” [s. 349], ma dotkliwe poczucie straty. Cały tom zamyka zaś zdanie: „Cóż mogła powiedzieć o sobie i o Ralphie Gillespiem poza tym, że był jej bliski, bliższy od wszystkich mężczyzn, których kiedyś kochała?" [s. 350]. Lynch dowodzi, że owa śmiertelna pomyłka Ralpha jest figurą uwięzienia w Hanratty i miarą relatywnego sukcesu Rose, zdolnej do określenia samej siebie nie poprzez siłę miłości, której poszukuje przez cały czas w rozmaitych wcieleniach, ale poprzez złożoną relację z miejscem, gdzie rozpoczęła swą przygodę ze światem $^{26}$. Rose buduje siebie wobec wielu swoich możliwych odbić/wersji: jest zatem i nie-Flo i nie-Ralphem (mniejsza już, czy i Ralph jest tu kolejną wersją klauna Munro) i nie-Miltonem Homerem, choć wszyscy oni składają się na Hanratty w niej.

Dziewczęta i kobiety mają podwójne zakończenie. W pierwszym z nich Del, wyzwoliwszy się z męczącego związku z Garnetem Frenchem, małżeństwo z którym uwięziłoby ją w Jubilee, przeżywa, świadoma własnej niekonsekwencji, rozpacz rozstania:

Zawróciłam do korytarza i spojrzałam na swoje niewyraźne, wykrzywione i zapłakane odbicie w lustrze. Przyglądałam się sobie, ból nie ustępował. Zaskoczyło mnie, że ta cierpiąca osoba to ja. Bo wcale nie byłam sobą. Patrzyłam. Patrzyłam i cierpiałam. Powiedziałam do lustra wers z Tennysona [...] Powiedziałam to z całą szczerością i ironią: „Nie przybywa, rzekła” [s. 333].

Te słowa ,jednego z najgłupszych wierszy”, jakie znała, wyzwalają w niej kolejny atak płaczu. Potem jednak idzie do kuchni i przy kawie czyta w gazecie dział ogłoszeń o pracy:

Po pewnym czasie poczułam wdzięczność wobec tych drukowanych słów, nieznanych możliwości. Istniały miasta, szukano telefonistek; przyszłość mogła się obyć bez miłości czy stypendiów. Oto wreszcie bez marzeń i oszukiwania samej siebie, odcięta od błędów chaosu przeszłości, z powagą i prostotą, $\mathrm{z}$ niewielką walizką w ręku, wsiadając do autobusu jak bohaterki filmów, które opuszczają dom, klasztor, kochanka - mogłam zacząć prawdziwe życie. „Garnet French, Garnet French. Garnet French. Prawdziwe życie”" [s. 334].

26 „I will argue and conclude below that Munro in Who does present the mature Rose as having achieved more of a stable sense of identity than Heble allows; and, what is as remarkable, Rose does so in relation to place and not to the ideal of a reifying love that she chases around most of the stories of this cycle" (tamże, s. 76). W kwestii pracy przywołanej tu polemicznie przez autora zob. A. Heble, The Tumble of Reason: Alice Munro's Discourse of Absence, Toronto 1994. 
Kolejny raz mamy tu do czynienia $\mathrm{z}$ wariantem motywu sobowtóra - tym razem w postaci zwierciadlanego odbicia przynoszącego bohaterowi wiedzę o sobie jako "obcym”. Munro buduje owo pierwsze zakończenie powieści w sposób dużo bardziej wyrafinowany niż poprzez ten mocno konwencjonalny chwyt. Mamy tu bowiem grę z własnymi przeżyciami ujętymi w budujący dystans cudzysłów, przepuszczonymi przez filtr filmowej fikcji, pojawiającymi się w ramach przeszłego i przyszłego, potencjalnego i dokonanego "prawdziwego życia”.

Drugie zakończenie stanowi fragment zatytułowany Epilog. Fotograf. Poznajemy w nim artystyczne plany Del, jej projekt szalenie gotyckiej powieści, w której w fikcyjnych rolach obsadza rzeczywistych mieszkańców Jubilee, odpowiednio modyfikując ich losy. W finałowej scenie Dziewcząt $i$ kobiet Del spotyka pierwowzór jednej ze swoich postaci, Bobby'ego Sherriffa ${ }^{27}$, mężczyznę, który jest na przepustce jako pensjonariusz szpitala psychiatrycznego. Ten zaprasza ją na werandę własnego domu, częstując kawałkiem własnoręcznie upieczonego tortu. Del komentuje tę scenę w myślach: „Tak zręcznie rozprawiłam się z rzeczywistością, a ona powracała nadal, niezgłębiona" [s. 347]. To wtedy pojawia się owa słynna fraza o życiu w Jubilee, banalnym, zdumiewającym, niepojętym, którą w tekście puentują zdania pomijane dość często przez cytujących:

Nie przypuszczałam, że kiedyś będę go tak złakniona. Że zapragnę spisać wszystko, nienasycona i zbłąkana jak wujek Craig ${ }^{28}$, gdy tworzył swoją historię. Sporządzałam rozmaite listy. Spis wszystkich sklepów [...] przy głównej ulicy. Spis rodów, nazwisk na nagrobkach na cmentarzu [...] Takie mozolne próby zbliżenia się do prawdy graniczą wręcz z obłędem, rozdzierają serce. I żadna lista nie objęłaby tego, na czym mi zależało, bo zależało mi na najdrobniejszych szczegółach, na każdym słowie, zdaniu [...] zapachu, wyboju, bólu, rysie i złudzeniu. Chciałam uchwycić to wszystko i połączyć w spójną całość. Na zawsze [s. 349].

Jeśli jednak prześledzić, skąd bierze się ten Proustowski odruch, przepuszczony tu przez świadomość nieuchronnej klęski wpisanej w ów projekt,

\footnotetext{
27 Kolejne wcielenie matko-podobnego klauna.

28 Rękopis, po śmierci brata, wręczają Del jego siostry, licząc na to, że spisze na podstawie tych notatek historię Jubilee. Ta, uważając tekst za całkowitą pomyłkę, wtyka pudło z nim w jakiś kąt. Po latach, wezwana przez matkę do pomocy przy sprzątaniu zalanej piwnicy, znajduje te zapiski, które przybierają postać „przemoczonego na wylot wielkiego pliku papierów”: „Przypomniało mi się, jak odprowadzały wzrokiem rękopis, gdy opuszczał ich dom w pudle zamkniętym na kłódkę, i poczułam skruchę, tę wątłą skruchę, której towarzyszy okrutna, niezmącona satysfakcja" (s. 93).
} 
okaże się, że w jego tle jest gest Bobby'ego Sherriffa, który, wiedząc, że Del chce wyjechać z Jubilee, życzy jej szczęścia:

I zrobił dla mnie coś specjalnego, ten jeden jedyny raz, wyłącznie dla mnie. Uniósł się na palcach jak tancerka, jak gruba balerina. Uśmiech, którym mnie przy tym poczęstował, był nie tyle żartobliwy, ile demonstracyjny, i zdawał się mieć znaczenie symboliczne, jak znak, a raczej słowo z nieznanego mi alfabetu. Pragnienia innych i ich dary przyjmowałam wtedy naturalnie, niemal odruchowo, jakby mi się należały. - Tak - odpowiedziałam, zamiast podziękować [s. 350].

Owa zamykająca powieść afirmacja ${ }^{29}$ stanowi, jak się zdaje, przejaw docenienia daru otrzymanego na drogę z Jubilee od kogoś, kto tego miasteczka nigdy nie opuści. Gest Billy'ego jest rodem z karnawałowo-groteskowego świata Miltona Homera i stanie się zapewne jednym z punktów na liście rzeczy niedających się „uchwycić i połączyć w spójną całość, na zawsze”. Ale jednocześnie domyka opowieść o Jubilee, sprawiając, że przybiera ona jakąś formę, nawet jeśli niemożliwą i ułomną zarazem.

Del i Rose niosą w sobie Jubilee i Hanratty teatralizując je, przerabiając na fikcję, powielając $w$ szeregu odbić. Ale nie są przez te miejsca nawiedzone, może dlatego, że obie wywodzą się z "pomiędzy” i rozumieją związek „ciasnego kąta” z „całym światem” "30. Nie tkwią ani w pułapce tych miejsc, ani w ułudzie ucieczki przed nimi. Uwolnione od Jubilee i Hanratty i z nimi związane, doskonale wiedzą, jakie tajemnice potrafi skrywać kuchenne linoleum.

\section{In Canada, in the House, in the Kitchen, on the Linoleum Floor: About Alice Munro's Short Stories}

\section{Summary}

The article analyzes two texts by the Canadian Nobel Prize winner, Alice Munro - Lives of Girls and Women and Who Do You Think You Are?

29 Dorota Filipczak zestawia oczywiście ten fragment ze słynnym zakończeniem monologu Molly zamykającego Ulissesa Joyce'a. O ile jednak, jak pisze, interpretowane jest ono jako "«przejaw afirmacji erotyzmu», «Yes» w ustach Del brzmi zupełnie inaczej niż ustach Molly. Molly w najlepszym wypadku może kształtować swoje życie erotyczne i kulinarne, ale nigdy nie będzie go tworzyć" (D. Filipczak, Pod "powierzchnią życia” - twórczyni i Femme Maison w prozie Alice Munro, s. 225).

30 To oczywiście aluzja do wiersza Konstantinosa Kawafisa Miasto: „Nie ma dla ciebie okrętu nie ufaj próżnym nadziejom/ - nie ma drogi ku innej stronie./ Jakeś swoje życie roztrwonił/W tym ciasnym kącie, tak je w całym świecie roztrwoniłeś", przeł. Z. Kubiak. 
Both books draw from the Bildungsroman tradition, and given such origin, they rather seem to represent the genre of short story novel than that of short stories collection. The article's author concentrates on the manner in which Munro depicts the coming of age of protagonists while using certain aspects of space and the Gothic convention.

Keywords: Canadian literature, short story novel, Bildungsroman, Alice Munro, Gothic, Southern Ontario Gothic, space, place, location 